\title{
Desolação, dor e agonia nas paisagens e no EU De Cassia- NO RICARDO
}

EvALDo BALBINO*

\section{RESUMO}

Este artigo discute sobre a poesia de Cassiano Ricardo. Mais especificamente, sobre a representação das paisagens e do eu na obra do autor. Os versos do poeta apresentam desolação, dor e agonia. A poética de Cassiano representa um espaço mítico do Brasil, transformando-o numa paisagem nos moldes do grupo Verde-Amarelo constituído nos anos de 1920 na literatura brasileira, mas também apresenta um olhar agônico sobre o Brasil e o mundo através de densas e contundentes imagens poéticas. Para a minha abordagem, uso teóricos que discutem o conceito de paisagem e principalmente faço leituras de poemas do autor paulista.

Palavras-chave: Cassiano Ricardo. Poesia. Paisagem. Desolação.

Situado tradicionalmente no movimento modernista brasileiro Verde-Amarelo ou Verde-Amarelismo, o poeta paulista Cassiano Ricardo (1895-1974) é aproximado, sob muitos aspectos, dos escritores que com ele constituíram esse grupo: Menotti del Picchia (1892-1988), Plínio Salgado (1895-1988) e Guilherme de Almeida (1890-1969). O movimento Verde-Amarelo constituiu-se como forma de reação ao modelo nacionalista preconizado pelo escritor Oswald de Andrade, defendendo o patriotismo em excesso e tendo clara tendência nazifascista em certos desdobramentos seus. Em 1927, o Verde-Amarelismo transformou-se na Escola da Anta ou Grupo Anta. Este nome foi escolhido pelo grupo como

Professor Doutor da Universidade Federal de Minas Gerais/UFMG, Belo Horizonte, Minas Gerais, Brasil.

E-mail: evaldo_balbino@yahoo.com.br. ORCID iD: https://orcid.org/0000-0001-81583989 
representação da nacionalidade brasileira, dado o contexto mítico desse animal na cultura tupi - principal tribo indígena brasileira.

No seu movimento ufanista, o grupo Verde-Amarelo buscou uma estética de exaltação do Brasil e, ao mesmo tempo, de hostilidade às proveniências estrangeiras. Cassiano Ricardo, principalmente no seu livro Martim-Cererê (1928), decantou nosso país, promovendo nas páginas da obra predominantemente uma mitificação dos processos migratórios, forçados ou não, para as terras brasileiras, bem como construiu uma narrativa estética muitas vezes dentro dos pontos de vista dos poderosos, ou dos opressores e não dos oprimidos.

No seu canto aos bandeirantes, Cassiano nos fala de gigantes adentrando as matas brasileiras. No seu nacionalismo ufanista e mitificador do avanço bandeirante pelas matas brasis, comparece o verdeamarelismo com seus preconceitos em relação aos sujeitos sujeitados ao longo da nossa história. Assim ocorre em relação, por exemplo, aos rituais antropofágicos de algumas tribos indígenas contrastados com a civilização trazida pela Europa: "Ali, o índio carniceiro / não gosta de presa incauta. / Quando come um prisioneiro / tira-lhe um osso da perna / e sai tocando flauta" (CASSIANO RICARDO, 1957, p. 149). Se temos neste trecho uma expressão forte ("índio carniceiro") a reforçar o aludido preconceito para com os sujeitados de nossa história, vemos também uma ironia e um consequente humor na imagem do osso da perna servindo de flauta ao aborígene. Essa imagem relativiza, de certo modo, a mitificação do bandeirante e a "barbárie" do índio. Os sertões brasileiros, mesmo representados com belíssimas imagens poéticas, não deixam de ser um espaço a ser explorado pelos mais fortes belicamente. As léguas e léguas vencidas surgem de modo telúrico como se fossem uma cobra mitológica: "Cada légua possuía uma cabeça / de montanha e, como cauda, um rio. / Parecia uma cobra mitológica / fulgindo sob a escama d’água espessa / e com a cauda enrolada na cabeça” (CASSIANO RICARDO, 1957, p. 163).

Ao longo da obra de Cassiano Ricardo, no entanto, podemos ler uma poesia que representa uma natureza e mais paisagens em risco, riscadas pelos rastros humanos com suas ganâncias, seus medos, suas contradições. 
Percebemos que, ao lado do louvor à construção mítica de um Brasil, há também na sua poética um olhar desolador perante as paisagens. E isso pelo fato de o sujeito poético enxergar destruição e ruínas, dores e agonias dum mundo que reverberam no olhar que olha, nas mãos que escrevem os seus poemas belos mas doloridos.

Para entender as construções paisagísticas (ideias de Brasil e dos sujeitos que para ele vieram e nele viveram e vivem, cenários outros e específicos, o planeta Terra etc.) de Cassiano Ricardo, busco aqui o conceito de paisagem, que se torna singular no quadro de uma geografia efetivamente humanista, nos termos de Cosgrove (1998). Para o geógrafo, a paisagem, ao contrário de lugar, diz sobre a nossa posição no esquema da natureza. Mais do que as ideias de espaço ou ambiente, o conceito de paisagem nos diz que podemos conhecer esse esquema apenas através da consciência e da razão humanas. No caso de Cassiano Ricardo, podemos ver isso através de sua poética.

Do mesmo modo, Luiz Otávio Cabral, na esteira de Cosgrove, disserta sobre uma corrente humanista do pensamento geográfico:

o universo da geografia constitui-se não somente de países, cidades, propriedades agrícolas, mares, relevo, clima, etc., mas também de ideias, sentimentos, imagens e representações. [...]. Em outras palavras, pode-se dizer que a perspectiva humanista focaliza-se no estudo da imaginação e ação humanas e na análise objetiva e subjetiva de seus produtos (CABRAL, 2000, p. 35).

Cabral também nos chama a atenção para um olhar sobre as partilhas entre sujeito e paisagem e sobre o modo como se dá a interação entre ambos:

Sob uma perspectiva humanista é preciso deslocar a atenção do objeto externo para os processos que ocorrem com os sujeitos que interagem com a paisagem. Não no sentido de determinar com precisão as forças físicas e psíquicas envolvidas, mas de descrever e analisar a maneira pela qual eles partilham essas relações existenciais com o entorno (CABRAL, 2000, p. 38-39). 
Já que a paisagem é uma construção/representação feita pelo sujeito a partir das suas relações com os espaços e os lugares, podemos falar duma dinâmica da construção da paisagem, num processo que passa pelos sentidos humanos nos termos de Michel Collot:

A paisagem não é apenas vista, mas percebida por outros sentidos, cuja intervenção não faz senão confirmar e enriquecer a dimensão subjetiva desse espaço, sentido de múltiplas maneiras e, por conseguinte, também experimentado. Todas as formas de valores afetivos - impressões, emoções, sentimentos - se dedicam à paisagem, que se torna, assim, tanto interior quanto exterior (COLLOT, 2013. p. 26).

O arquiteto e urbanista Leo Name, alinhado a essas discussões conceituais, diz-nos da paisagem como sendo ela mais do que uma espaço estático. Ela é antes de tudo a produção do espaço e a representação dele feita por sujeitos. E conclui o autor:

Portanto, os significados da palavra "paisagem", também ambíguos, revelam que ela não é apenas a condição estática de um espaço observado por um sujeito - individual ou coletivo, que tem seus valores e crenças - [...]. É também a produção do espaço e a representação do espaço por estes mesmos sujeitos, o que insere uma perspectiva dinâmica e diacrônica em sua conceituação e significados (NAME, 2010, p. 165).

Se a paisagem representada é leitura que dela se faz, assim podemos falar de uma geografia da subjetividade, geografia essa que se perfaz no curso da poesia. Aqui, no caso, da poesia de Cassiano Ricardo. O poeta transforma em forma poética a sua relação com os espaços. As paisagens urbanas e rurais construídas pelo poeta são atravessadas pelo olhar do sujeito que as fotografa com sua lente poética. No caso de Cassiano, busco aqui mostrar o que há de representação da degradação dos lugares e das pessoas. Caminhemos, pois, por essa geografia literária do poeta paulista.

Em seu segundo livro, A frauta de Pã (1917), temos o poema “Jeremias", no qual se apresenta um cunho metafísico que não deixa, 
porém, de plantar raízes na natureza. Através do estado anímico do sujeito poético, tem-se a fusão entre o eu e a natureza, apresentando ambos dor e desolação:

Sou um curvo chorão. Meu fado é, noite e dia, chorar à margem desta água clara e sonora.

Caem-me os ramos, como em lágrimas... Dir-se-ia

que o próprio rio foi, por mim, chorado agora.

Vós que vos descuidais só em viver de alegria

Chorai e entendereis uma árvore que chora!

Pois não é apenas meu, o mal que me angustia, mas o que, no chão duro, absorveis de hora em hora.

Chorai, e entendereis a razão desta mágoa.

E eu vos hei de sentir, na dor de cada ramo

que escorre do meu rosto e cai ao rosto d'agua.

E seremos irmãos no pranto, que verterdes.

Pois choro o vosso choro, e os galhos que derramo

São - choradas por mim - vossas lágrimas, verdes

(CASSIANO RICARDO, 1957, p. 34).

Ao atribuir-se o adjetivo "curvo", o sujeito poético já se mostra por inteiro, deslocado, atravessado por incômodos. Seu fado é chorar. Ele é uma árvore chorando à beira do rio. Mas esse choro é universal, pois a voz poética conclama os seus interlocutores (a quem chama de vós) para sentirem seu choro e perceberem que este são lágrimas de todos e por todos. Cassiano Ricardo retoma aqui a figura bíblica de Jeremias, o autor das apelações ao povo de Israel e de Judá, reinos hebreus divididos. E a Jeremias também se atribui o Livro das Lamentações (BÍBLIA DE ESTUDO ALMEIDA, 2013), que é um poético choro, uma poética conversa com Deus pelo fato de Judá ter caído nas mãos do domínio da Babilônia. Assim como o profeta lamentava diante de sua terra feita paisagem desolada, assim o poeta chora pela humanidade. 
Em “Paisagem submarina”, vemos o tom de escuridão e dor:

No antro submarino, onde os pólipos têm qualquer coisa de humano em seu mistério e são galhos de sangue aí chorado por alguém que naufragou depois de haver lutado em vão;

nesse mundo ignorado, ou nessa escuridão que é toda azul por fora e só monstros contém é que irei enterrar o meu único bem... Náufrago - devo estar onde os outros estão.

Bem que é meu, ficará guardado onde só eu o saiba, como alguém que, fugindo a um ladrão, se tornou o ladrão daquilo que já é seu.

Estarei nesse caso? Ah! quanta gente que, pra esconder o seu bem, busca o escuro e não vê que uma estrela reluz melhor na escuridão... (CASSIANO RICARDO, 1957, p. 35)

Uma paisagem submarina se mostra como antro, gruta profunda e escura, furna. E a subjetividade do sujeito poético enxerga nos animais invertebrados do fundo do mar algo de humano. Novamente aqui o estado anímico do ser: a integração entre o sujeito e a paisagem que ele constrói. Observem-se as imagens dos mistérios, dos galhos de sangue chorando por náufragos que lutaram em vão. $\mathrm{O}$ mar apresenta superfície azul, mas o seu dentro guarda escuro e monstros ignorados, lá onde o sujeito se coloca também como todos os náufragos e pólipos chorando. $\mathrm{O}$ próprio sujeito se sente naufragado. A despeito da escuridão e do desejo de se guardar nas profundezas marinhas, reconhece-se o paradoxo: "uma estrela reluz melhor na escuridão". A dor construída no poema, o risco dessa dor no fundo do mar representado - tudo isso é mais claro e rutilante pela força da poesia. 
As relações entre os sujeitos e os espaços, essas construções de paisagens, são chamadas por Eric Dardel (1952) de geograficidade. Essa ideia encerra todas as respostas e experiências que temos com/nos ambientes nos quais vivemos. Sendo positivas, são experiências topofílicas; quando negativas, desagradáveis ou repulsivas, são experiências topofóbicas. Ambas as experiências estão associadas com o caráter do ambiente e com os valores e atitudes daqueles que o experienciam. Daí o fato de nossas relações com o entorno serem atravessadas por sentimentos de beleza e feiura, de alegria e sofrimentos, de acertos e erros (DARDEL, 1952, p. 2).

No poema "Tarde no campo", escreve o poeta Cassiano Ricardo:

Vem a tarde, afinal... $\mathrm{E}$ as quérulas avenas de um rancho de zagais, em chorosa surdina, põem trêmulos de dor, de saudades terrenas, no claro-escuro da tristeza vespertina...

Ao dorido langor de agrestes cantilenas, a lâmpada do ocaso as coisas ilumina; o crepúsculo entreabre as rosas e as verbenas, como a interrogação da dúvida divina.

Longe, a tarde se estorce, em violácea agonia.

Essas horas de susto e de melancolia, como é triste ao pastor transviado compreendê-las!

Pelas moitas sem luz, pelos ermos escampos, com cabelos de luar e olhos de pirilampos, desce a Noite, tangendo o rebanho de estrelas... (CASSIANO RICARDO, 1957, p. 36)

Nesta composição de rasgos parnasiano-simbolistas e decadentistas, a hora do crepúsculo é poetizada. Se há nestes versos uma questão de estética da época, ou seja, temos aí um Cassiano Ricardo reinscrevendo modelos formatados por estéticas com suas regras, não deixamos de notar imagens fortes, sui generis. Assim vemos quérulas avenas em chorosa 
surdina, o claro-escuro da tristeza vespertina, a interrogação da dúvida divina, uma tarde retorcida e uma violácea agonia. A palavra violácea reforça o caráter forte do sentimento agônico. Tudo isso são imagens a compor o lusco-fusco da natureza e do ser que o contempla. Se falamos aqui de algo recorrente em obras parnasianas / simbolistas / decadentistas, reforçamos o caráter agônico da natureza e do eu em Cassiano Ricardo, e isso já no seu segundo livro, ou seja, A frauta de Pã, de 1917.

Em "O gato tranquilo", um singelo soneto da mesma obra, a voz poética de Cassiano nos mostra um felino "vendo tudo através a cor verde dos olhos". O gato é uma "Onça que não cresceu", "um professor de silêncio e virtude". O segundo terceto arremata o poema: "Gato que sonha assim, se algum dia o entenderdes, / vereis quanto é feliz uma alma que se ilude, / e olha a vida através da cor de uns olhos verdes" (CASSIANO RICARDO, 1957, p. 37). Olhar a vida com olhos verdes, esta cor da esperança, não é o caso do poeta. Mesmo que o verde-amarelismo de Cassiano Ricardo, conforme já dito, tenha erigido miticamente heróis de uma história contada com apagamento de interesses das classes dominantes, portando promovendo um tom idílico para as relações entre colonizados em colonizadores, na sua poética como um todo vemos também outro movimento, o do esgarçar da natureza, das paisagens, da vida, do mundo. Que os olhos verdes fiquem apenas com os felinos!

No seu terceiro livro, Vamos caçar papagaios (1926), nolongo poema "A florada”, cria-se uma alegoria para a cultura do café no Brasil, mormente no interior de São Paulo. "O cafezal, branco de flor, / amanheceu que é uma grinalda / de princesa” (CASSIANO RICARDO, 1957, p. 52). O agricultor, que na verdade aqui é o proprietário rural, é o noivo de uma noiva de vestido farto e colorido: a árvore do café. Utilizando-se da personificação, prossegue a voz do poeta:

\footnotetext{
Que ficou noivo da riqueza

e sai passear com a sua noiva.

Ele falando só de amor, ela arrastando o seu vestido quase sem fim, de tão comprido,
} 
quase impossível de tão branco,

que de tão branco e tão comprido

por onde passa vai deixando

o chão assim... de tanta flor!

(CASSIANO RICARDO, 1957, p. 52).

Na metáfora do grão de café como "esmeralda", o poeta nos diz das riquezas geradas pela cafeicultura do Brasil no início do século XX. Apesar de retratar aqui a elite cafeicultora do país, vemos uma esperança (o verde do café) que se esvai com a oscilação de um mercado internacional a colocar em xeque a esposa "riqueza" do latifundiário e a ele próprio. $\mathrm{O}$ café enxuto, cor da noite, é luto antecipando o que vem logo em seguida no poema:

Então a "baixa" sobe a serra
e o lavrador, dono da terra,
que dormiu rico acordou pobre.
Vence a hipoteca, pior que a geada
quando derriça uma florada.
Faz-se fogueira, grita o povo...
E era uma vez, triste e sem glória
ei-lo contando a sua história.
É o fazendeiro, com certeza,
que ficou viúvo da riqueza. (CASSIANO RICARDO, 1957, p. 53-54).

Apesar do tom otimista e nacionalista do fim do poema, pois o fazendeiro é um herói obscuro a abrir a janela do futuro, o que vemos é um infindável movimento de partida e de retorno ao ponto de partida, pois é com florada que começa e que termina o texto, como a se mostrarem os altos e baixos dos empreendimentos do cafeicultor.

No também longo poema "A cidade dos sapos", que nos lembra aqui o texto "Os sapos" de Manuel Bandeira, vemos um Cassiano Ricardo extremamente engajado com questões sociais. Enquanto em Bandeira se vê encenada a querela entre a estética modernista e a fôrma parnasiana e 
seus congêneres, aqui agora, em Cassiano, temos o martelar monótono sobre as condições de vida pobre e miserável dos operários suburbanos duma grande cidade.
Os sapos que eu conheço no bairro onde resido, gritam, desde o começo da noite, ao meu ouvido. Gritam a noite inteira; porém, são mais humanos, sob um certo sentido, que os de Manuel Bandeira. Pois não são parnasianos e nem tomam parte em discussões sobre arte.

São, todos, operários e dão-se a ofícios vários (CASSIANO RICARDO, 1957, p. 59).

Observemos que os sapos de Bandeira também são metáfora ou alegoria de seres humanos, porém de artistas discutindo arte, as formas de arte. Já os sapos de Cassiano Ricardo encarnam a arte de viver, ou melhor, de sobreviver em meio às dificuldades. Eis o espaço de que se fala: um bairro operário, paisagem da periferia, com suas mazelas e necessários elementos culturais para o descanso da exaustão. A voz poética de Cassiano evoca para seus sapos uma condição melhor do que a dos sapos de Bandeira; se sofrem nos seus ofícios, são filhos de Deus: "Neste ponto, os meus sapos, / que também batem papos, / já diferem dos seus... / pois são filhos de Deus" (CASSIANO RICARDO, 1957, p. 59).

E segue nos versos a enumeração poética das diferentes profissões e pessoas com suas atividades: ferreiro, carpinteiro, pedreiro, bate-sola, uma intanha viúva, um sapo bruxo, um filósofo. Em contraposição às imagens duma Nova York mais aérea e maior que a da fotografia, temos, pelo muito 
ruído do trabalho operário do ferreiro, uns duzentos castelos construídos no charco. No palácio onde mora, o carpinteiro vive serrando tábuas, nada de alvenaria. Com apelo ao vocativo, a voz do poeta irmana-se à do proletário: “Ó sapo carpinteiro, / serra as minhas mágoas!" (CASSIANO RICARDO, 1957, p. 60). Tudo o que o pedreiro constrói, “a água da enchente arrasa...” (CASSIANO RICARDO, 1957, p. 60). Na pobreza da existência, o elemento religioso poderia vir para a salvação, mas não se mistura no charco onde vivem os pobres: "Lá longe, um bate-sola / fabrica o azul sapato / com que Nossa Senhora / virá do céu, num barco / de lua, só pra vê-lo, / sem se sujar no charco" (CASSIANO RICARDO, 1957 , p. 60).

O sapo filósofo é o ser que pensa, fazendo indagações sem respostas: "Outro sapo é filósofo: / quem será que me pôs / na lama, tão de rastros / sem ficar com a mão suja? / quem será que criou / o perfume das rosas? / quem no céu espalhou / o ouro aceso dos astros?” (CASSIANO RICARDO, 1957, p. 61). Tais perguntas apontam para possíveis respostas não dadas. E nessas respostas, poderia entrar o ser divino ou poderiam ser escancaradas as ações humanas classistas que reforçam constantemente as divisões entre as pessoas, os exploradores e os explorados, os que estão em seus palácios e que, concentrando renda, colocam seus subordinados no charco, de rastros na lama.

Durante a noite, o bairro operário acende os lampiões. A imagem dos lampiões verdes de pirilampos abre uma possibilidade de descanso, de esperança, de alegria do povo: "Hoje tem espetáculo! / gritam todos os sapos. / Hoje tem coisa boa! / [...] / e a algazarra plebeia / por todo o brejo ecoa" (CASSIANO RICARDO, 1957, p. 61-62). No meio da festança, no entanto, a lagoa, ou melhor, o charco, encontra na arte uma representação da própria vida subalterna. $\mathrm{O}$ cinema comparece sob os auspícios da Disney, empresa norte-americana cujo imperialismo cultural já se fazia sentir no Brasil no início do século XX: "Ou então é o cinema / do brejo que funciona, / exibindo um desenho / animado de Disney: / Um sapo se suicida / por causa de uma estrela" (CASSIANO RICARDO, 
1957, p. 62). As imagens do alto e do baixo, do sapo e da estrela, para além de um drama romântico, apontam para as divisões, respectivamente, entre riqueza e pobreza.

Apesar dessa representação alegórica e realista, na noite do bairro pobre se faz festa. Por necessidade de descanso da luta diária e/ou por anestesia advinda duma falta de consciência de classe (alienação), a algazarra se presentifica, as palmas ressoam, e o ronco dos sapos repete o "foi, não foi." (CASSIANO RICARDO, 1957, p. 62).

A alegria é fugaz, pois a realidade chama a todos os sapos para a dureza da vida. E a luta continua, o suor insiste em descer nos corpos na labuta diária. E o sentimento do caráter vão de uma vida assim levada toma a todos. Nesse sentimento, desparece a alienação. A realidade abre os olhos dos sapos trabalhadores:

No outro dia, porém, quando chega a alvorada, loura, de olhar cerúleo:

- por que tanto barulho? que aconteceu? que foi?

Vai-se ver; não foi nada.

E tudo continua

no mesmo pé, na mesma

luta desesperada.

Eu suo: você sua...

tudo por quê? por nada.

(CASSIANO RICARDO, 1957, p. 62-63).

O verso "no mesmo pé, na mesma”, por meio de repetição vocabular, dá o tom de mesmice à vida dos sapos, o que ecoa, a partir dos versos de Manuel Bandeira, o famoso "foi, não foi”. O que se constitui é a monotonia dum discurso que diz da monotonia duma vida que não muda, que sempre se perfaz subjugada a explorações de humanos sobre humanos, pois que Deus não tem nada a ver com isso: 
Ó pobre sapo-boi,

foi Deus que assim te fez?

foi Deus que assim te quis?

ao menos, uma vez,

responde: foi? não foi?

Pobre mundo infeliz

que diz e se desdiz

tocando o "foi, não foi",

ininterruptamente.

$\mathrm{E}$ a gente pede bis...

Deus não tem dó da gente.

(CASSIANO RICARDO, 1957, p. 63).

Se Deus não tem dó é porque, em suma, cabe à sociedade fazer o seu papel em prol da justiça. Compete a ela rever as questões sociais no que elas trazem de exploração de muitos por uma minoria. E o poema de Cassiano Ricardo, aqui, faz a sua parte. É discurso que olha para um espaço, o bairro operário, e denuncia o descaso e o desleixo dum mundo feroz em relação aos que trabalham para sustentar a humanidade.

Esse olhar do poeta para um país atravessado de diferenças, de lutas e injustiças, convive em contraste, como já dito, com os olhos verdeamarelos a apregoarem o mito da tranquila miscigenação brasileira. Mesmo que em Cassiano Ricardo bandeirantes sejam heróis, que Portugal tenha vindo tão somente para trazer fé e contribuir com nossa cultura, a poesia do paulista não deixa de dizer a dor dos oprimidos. Assim ocorre, ainda no livro Vamos caçar papagaios (1926), no poema "Sangue africano". Mesmo falando duma redenção dos escravos, o poeta não consegue eximirse de dizer a dor do outro, a que atravessa séculos e gerações e que ainda se faz presente no momento em que o poeta escreve; dor que se faz presente até os nossos dias:
Ó meu Pai-João, por que choraste?
E ele nem me voltou o rosto de carvão. 
Como um grito de dor, dentro do coração, pareceu-lhe escutar o clamor da senzala.

E grandes lágrimas de opala

lhe estrelaram a face negra, à hora do jongo, como se o pobre preto, em sua noite escura, conseguisse acender as estrelas do Congo... (CASSIANO RICARDO, 1957, p. 73).

A despeito do ufanismo obnubilador das lutas sociais, ufanismo esse predominante nos momentos em que Cassiano fala da história do Brasil e faz isso do ponto de vista das classes dominantes, estamos vendo que não falta certa criticidade por parte do autor em sua obra, o que dá um caráter polifônico a seus textos em termos de ideologia colonizadora e de concepções dos processos de miscigenação nas paisagens brasileiras. Se há uma exortação ao avanço paulista sobre os sertões - "Mais longe descansa o sertão imortal. / A voz da araponga até hoje desata / o seu grito, transfundido em metal. / Foi onde o paulista, que nunca descansa, / fundou o país da Esperança” (CASSIANO RICARDO, 1957, p. 74) -, há também a consideração de sofrimentos em meio aos sonhos, por parte tanto de índios, quanto de lusos e negros: “... e homens, filhos do sol (os índios) / homens filhos do luar (os lusos) / homens filhos da noite (os pretos) / aqui vieram sofrer, aqui vieram sonhar" (CASSIANO RICARDO, 1957, p. 74). Essas duas posturas discursivas estão num mesmo poema: "Exortação".

No livro Martim-Cererê (1928), no poema "A missa e o papagaio", ao chamar jocosamente a terra brasilis de Terra papagalorum, o poeta se mostra cônscio dos processos de aculturação aos quais a Terra de Santa Cruz foi exposta: "Depois acaba a missa / e então os papagaios / voltam, todos, pro mato, já falando latim...” (CASSIANO RICARDO,1957, p. 109-110). Esse voltar para o mato é a busca das raízes culturais, mas já é uma busca latinizada.

Ainda no mesmo livro, em "Mãe-preta", o cenário do canavial é cortado a lâmina, pois é espaço onde a dor e a injustiça muito imperaram 
sobre os ombros dos africanos escravizados no Brasil: "Quem é que está fazendo este rumor? / As folhas do canavial / cortam como navalhas: / por isso ao passar por elas / o vento grita de dor..." (CASSIANO RICARDO, 1957, p. 122-123). Esta imagem é exemplar dum espaço tornado paisagem dolorosa, visto sob a ótica da crítica social, sob a subjetividade que enxerga no espaço tudo o que nele ocorreu e ocorre em termos de ações humanas nefastas. O canavial em si é apenas um canavial, mas o olhar poético, associando-o ao povo negro escravizado no Brasil, realça o caráter cortante das folhas da cana.

Essa representação paisagística agônica, problematizadora, atravessada por um olhar que nas coisas vê o irremediável, constrói-se também no antológico poema "Serenata sintética", do livro Um dia depois do outro (1947): "Rua / torta. / Lua / morta. / Tua / porta" (CASSIANO RICARDO, 1957, p. 279). Esse cenário, definitivamente, não é para uma serenata. Todo e qualquer idílio é interceptado pela tortuosidade da rua, pela morte da Lua, pela porta que, com os sons oclusivos e surdos da palavra, barra qualquer canto ao amor, como se ela, a porta, estivesse fechada. Observemos que o poema, de fato sintético porque serenata não há, vai encadeando sons oclusivos como a obstaculizar qualquer possibilidade de algo positivo, afetivo. $\mathrm{O}$ cenário é desolador.

No mesmo livro, em "A flauta que me roubaram", tem-se uma busca pelo mito das origens felizes, o paraíso perdido, uma São José dos Campos (cidade natal do poeta) idealizada e localizada lá no passado. O sujeito poético busca situar-se "no tempo em que não havia / comunismo nem fascismo / pra nos tirarem o sono"; uma cidade pequena em que a ponte caía, mas restava a balsa para se atravessar o Paraíba; um lugar onde "O horizonte estava perto. / A manhã não era falsa / como a da cidade grande. / Tudo era um caminho aberto. [...] Só havia pirilampos / imitando o céu nos campos. / Tudo parecia certo. / O horizonte estava perto" (CASSIANO RICARDO, 1957, p. 280). O poeta insiste na proximidade do horizonte, daí a repetição do verso $O$ horizonte estava perto. Mas eis que entre os versos citados surge este: Tudo parecia certo. Parecer não é ser ou estar, mas antes é um verbo que aponta para uma modalização ao dizer- 
nos do atributo de algo no nível do engodo, da ilusão. Havia sim queda da ponte. Os pirilampos apenas imitavam o céu estrelado; não eram esse céu. E o poema continua. Havia erros nos votos, apesar das somas certas; havia ruas tortas, apesar de Deus escrever direito por elas. Tudo parecia o paraíso, mas não era. E a flauta roubada, aliás aludida no título do segundo livro de Cassiano Ricardo (A frauta de Pã, 1917), flauta aqui no sentido duma vida bucólica e idílica, nunca existiu. $\mathrm{E}$ isso porque a paisagem de São José dos Campos era cortada por contradições, arranhaduras: a corrupção entranhada nas eleições era uma dessas arranhaduras.

As arranhaduras nas paisagens, suas trincas e consequentes ruínas, são imagens que também voltam no livro $A$ face perdida (1950). O eterno retorno. No poema "Visita à casa paterna", as perguntas que se fazem são verdes, esperançosas, mas o que resta é o silêncio, um sangue soluçando. $\mathrm{E}$ isso porque a fotografia do outrora não refaz o tempo perdido, não o retorna para o agora: "Ouve-se o musgo caminhar, no muro, / entre as formigas. / A única coisa quieta / é a pedra / que me taquigrafa as palavras / e as rugas" (CASSIANO RICARDO, 1957, p. 410). Eis uma bela e dolorosa imagem: a secura da pedra e a sua quietude são o que resta de vida para a grafia das palavras e das rugas do poeta.

No seu livro Poemas murais (1950), Cassiano registra o sintomático poema "Coroa mural", texto-sintoma do que estamos chamando aqui de desolação, dor e agonia nas paisagens e no eu de Cassiano Ricardo:

\author{
Muro que hoje separa \\ os homens \\ em passado e futuro, \\ que divide, agora, \\ o coração em dois: em oriente \\ e ocidente. \\ Divide o sol em dois: \\ em dois mistérios. \\ Divide o mundo em dois: \\ em dois hemisférios. \\ Ou em dois cemitérios?
}


No labirinto

do desentendimento humano

$o$ anjo rebelde

se debate em busca

de uma saída.

E, ao mesmo tempo, é expulso

de uma cor para outra,

deixando os pés escritos

em areia e neve,

na rude geografia

das injustiças.

(Só a dor e as estrelas

são universais).

(CASSIANO RICARDO, 1957, p. 469)

A geografia é rude; o desentendimento humano impera e divide mundos; qualquer ato de rebeldia a esse estado de coisas resulta numa impossibilidade, restando apenas injustiças, restando rastros no que é frio e frágil, no que é areia e neve.

O poema prossegue indagando como destruir o Muro. Com as trombetas de Jericó? Com um novo concerto como o do grande arcoíris entre Deus e o seu povo? Com a lira de Anfíon em Tebas? O poeta, em suas indagações, apela até para o "sol de hidrogênio", metáfora para a bomba nuclear, como um ponto final para as divisões, ponto final que, pela morte, talvez possa irmanar as pessoas. Segundo o poeta, a noite (horas sem distinções) nos une, mas o dia (claridade que nos leva a divisões) nos separa. $\mathrm{E}$ ao fim prevalece a reafirmação do reconhecimento de que o homem separa, sempre: "O dia é geográfico. / A noite é universal. / Mas, se Deus ouvir rádio, / esteja onde estiver / ouvirá o meu grito: / por que a noite nos une / e o dia nos separa?" (CASSIANO RICARDO, 1957, p. 471).

As reflexões tecidas no poema dizem das invenções e culturas humanas a dividirem os seres humanos: passado e futuro, oriente e ocidente, hemisfério Norte e hemisfério Sul. E os hemisférios são, na verdade, cemitérios, já que nem a vida em si mesma é respeitada. Lendo o poema (publicado em 1950, portanto no pós-Segunda Guerra Mundial 
e num momento histórico, por exemplo, de Guerra Fria), não há como não pensarmos, retrospectiva e prospectivamente, nos próprios muros de Jericó citados pelo poeta, os quais, na narrativa bíblica, separavam povos inimigos entre si; não há como esquecermos as divisões entre exploradores e explorados, entre aristocracias encasteladas e povos mais à mercê da pobreza e das violências; não há como deixarmos de pensar nos isolamentos e nas edificações de muros - simbólicos ou reais -, como o erigido entre as duas Berlins ou o que Israel tem tentado construir na Cisjordânia para impor barreiras aos palestinos ou ainda o que o expresidente norte-americano Donald Trump tentou recentemente erigir para separar o México dos Estados Unidos.

No livro O arranha-céu de vidro (1954), em poema homônimo, o poeta nos oferece a marcante imagem dum edifício e duma cidade sob uma tempestade. Fala-se dos problemas urbanos em dias de forte chuva, denunciando-se o abandono a que é relegado nesse espaço o ser humano pobre:

Impossível descrever a tormenta

sobre a cidade, sobre o arranha-céu de vidro.

A hora do pânico.

Uma cintilação crua e os fios da iluminação pública e do tráfego síncope das palavras.

As ruas são rios, as casas dos pobres nadam como peixes nos alagadiços, rosa d'água que tombou do ar em pétalas de fogo.

(Os jornais naturalmente publicarão amanhã a fotografia do transeunte [que a enxurrada engoliu pela boca de um cano de esgoto). (CASSIANO RICARDO, 1957, p. 584).

A essa tormenta e a essa banalização e espetacularização da morte (fotografia do morto na enxurrada estampada nos jornais), surge no poema 
a imagem do imenso arco-íris a lembrar-nos da piedade de Deus, mas também a reforçar em nós a consciência de que ainda somos náufragos nesta paisagem criada:

Mas surge o arco-íris, grande flor celeste, girassol fantástico sobre o arranha-céu de vidro.

Arco-íris que fugiu da fábula e da Bíblia.

$\mathrm{O}$ arco de aliança, o sinal do armistício assinado entre Deus e as suas criaturas.

Arco no céu, e íris em nossos olhos pra nos lembrar que ainda somos náufragos. (CASSIANO RICARDO, 1957, p. 584-585).

O poema dá uma guinada para fazer críticas à humanidade pelo que há nela de negativo e pelo uso de sua inteligência em prol da desumanidade:

Ou porque a tempestade, hoje, perdeu o prestígio da fúria.

Ou porque uma faísca elétrica, inesperada, não é mais tétrica que uma cadeira elétrica, à hora exata.

Ó bárbara que se tornou santa, ó santo irmão do lobo.

Ou porque as grandes fúrias da natureza serão sempre pequenas diante da tempestade que os laboratórios de física anticeleste fabricam em silêncio. (CASSIANO RICARDO, 1957, p. 585).

Observemos que o nome de Santa Bárbara, protetora contra os raios e tempestades, comparece aqui em letra minúscula. Assim, o sentido de bárbara associa-se à ideia de um ser cruel, desumano, feroz. Daí a imagem 
do verso "ó santo irmão do lobo", numa referência à máxima de Thomas Hobbes (1979) de que o homem é o lobo do homem, já que, para o autor de Leviatã, o ser humano é naturalmente egoísta e mau.

Nas paisagens retorcidas (desoladas, doloridas e agônicas) que o ser humano vai criando e recriando, uma cadeira elétrica é mais tétrica do que a tempestade da natureza. Se há problemas urbanos e mortais em meio a tempestades da natureza, isso é fruto de ações humanas, de pobreza gerada, de crescimentos urbanos desenfreados e desordenados. Nessas paisagens retorcidas, a espécie humana é bárbara no sentido de cruel e desumana. Nessas paisagens retorcidas, a ciência se ergue contra o céu, produzindo tempestade medonha no silêncio: as bombas mortíferas. E do caos dessas paisagens retorcidas emerge a poesia, a sempre poesia buscando organizar o caos ao dizer dele.

Desolation, PAIN AND AGONY IN THE LANDSCAPES AND IN THE SELF OF CASSIANo Ricardo

\section{Abstract}

This article discusses Cassiano Ricardo's poetry. More specifically, about the representation of landscapes and the self in the author's work. The poet's verses present desolation, pain and agony. Cassiano's poetic represents a mythical space in Brazil, transforming it into a landscape along the lines of the Green-Yellow group created in the 1920s in Brazilian literature, but it also presents an agonized look at Brazil and the world through dense and forceful images poetic. For my approach, I use theorists who discuss the concept of landscape and mainly I read poems by the author from São Paulo.

Keywords: Cassiano Ricardo. Poetry. Landscape. Desolation.

DesolaCión, DOLOR Y AgONÍA EN LOS PAISAJES Y EN EL YO DE CASSIANO RICARDO

\section{RESUMEN}

Este artículo analiza la poesía de Cassiano Ricardo. Más concretamente, sobre la representación de los paisajes y el yo en la obra del autor. Los versos del 
poeta presentan desolación, dolor y agonía. La poética de Cassiano representa un espacio mítico en Brasil, transformándolo en un paisaje en la línea del grupo Verde-Amarillo formado en la década de 1920 en la literatura brasileña, pero también presenta una mirada agónica sobre Brasil y el mundo a través de imágenes poéticas densas y contundentes. Para mi enfoque, utilizo teóricos que discuten el concepto de paisaje y principalmente leo poemas del autor paulista.

Palabras clave: Cassiano Ricardo. Poesía. Paisaje. Desolación.

\section{REFERÊNCIAS}

BÍBLIA DE ESTUDO ALMEIDA. Lamentações. Barueri: Sociedade Bíblica do Brasil, 2013.

CABRAL, Luiz Otávio. A paisagem enquanto fenômeno vivido. Geosul, Florianópolis, v. 15, n. 30, p 34-45, jul./dez. 2000.

CASSIANO RICARDO. Poesias completas. Rio de Janeiro: José Olympio, 1957. COLLOT, Michel. Poética e filosofia da paisagem. Tradução Ida Alves. Rio de Janeiro: Oficina Raquel, 2013.

COSGROVE, Denis. A geografia está em toda parte: cultura e simbolismo nas paisagens humanas. In: CORREA, Roberto Lobato; ROSENDAHL, Zeny (org.). Paisagem, tempo e cultura. Rio de Janeiro: Editora da UERJ, 1998. p. 92-123.

DARDEL, Eric. L'Homme et la terre: nature de la realité géographique. Paris: Presses Universitaires de France, 1952.

HOBBES, Thomas. Leviatã. São Paulo: Abril Cultural, 1979. (Coleção Os Pensadores).

NAME, Leo. O conceito de paisagem na geografia e sua relação com o conceito de cultura. GeoTextos, v. 6, n. 2, p. 163-186, dez. 2010.

Submetido em 05 de março de 2021

Aceito em 19 de abril de 2021

Publicado em 30 de maio de 2021 